\title{
Bioelectrochemical investigations of aryl-alcohol oxidase from Pleurotus eryngii
}

\author{
Florentina-Daniela Munteanu ${ }^{\mathrm{a}}$, Patricia Ferreira ${ }^{\mathrm{b}}$, Francisco J. Ruiz-Dueñas ${ }^{\mathrm{b}}$, Angel T. Martínez ${ }^{\mathrm{b}}$, \\ Artur Cavaco-Paulo ${ }^{\mathrm{c}, *}$ \\ a University "Aurel Vlaicu" Arad, Faculty of Food Engineering, Tourism and Environmental Protection, Department of Chemical and Biological Sciences, Elena Dragoi 2, 310330 \\ Arad, Romania \\ ${ }^{\mathrm{b}}$ Centro de Investigaciones Biológicas, CSIC, Ramiro de Maeztu 9, E-28040 Madrid, Spain \\ ${ }^{\mathrm{c}}$ University of Minho, Department of Textile Engineering, Campus de Azurém, 4800-058 Guimarães, Portugal
}

\section{A R T I C L E I N F O}

\section{Article history:}

Received 11 December 2007

Received in revised form 22 February 2008

Accepted 27 February 2008

Available online $\mathrm{xxxx}$

\section{Keywords:}

Aryl-alcohol oxidase

Bioelectrochemistry

Graphite electrode

Kinetic

Redox potential

\begin{abstract}
A B S T R A C T
Aryl-alcohol oxidase (AAO) electrochemistry studies, using graphite-modified electrodes, are presented for the first time herein. The increase in current upon injection of the analyzed substrate was shown to be approximated by Michaelis-Menten type dependence. The calculated kinetic constants were used to characterize the native (non-mutated) recombinant AAO expressed in Escherichia coli, as well as the native enzyme and the F501Y and F501A variants expressed in Emericella nidulans. Results from cyclic voltammetry experiments conducted with the enzymes adsorbed on graphite electrodes or with the enzymes in solution (using glassy carbon electrode as working electrode) gave information on the redox potential of these enzymes.
\end{abstract}

(c) 2008 Elsevier B.V. All rights reserved.

\section{Introduction}

Lignin is a highly irregular biopolymer with an undefined structure. It is composed of oxygenated phenylpropanoid units, which are linked among them through various types of $\mathrm{C}-\mathrm{C}$ and $\mathrm{C}-\mathrm{O}-\mathrm{C}$ bonds [1-4], the last ones yielding a molecule with a high nonphenolic content. Due to these features, this macromolecule is rather refractory to biodegradation. In fact, in Nature only the white-rot basidiomycetes are able to degrade lignin in lignocellulosic materials. Effective lignin degradation by these fungi is achieved through a ligninolytic system constituted by laccases, lignin peroxidases, manganese peroxidases and versatile peroxidases [5]. Furthermore, some basidiomycetes have the ability to biosynthesize lignin-related compounds that can be used as intermediates in the degradation process.

Aryl-alcohol oxidase (AAO) provides hydrogen peroxide necessary for peroxidase activity during lignin biodegradation. This extracellular flavoenzyme is produced by ligninolytic fungi from the genera Pleurotus, Bjerkandera Trametes and Phanerochaete [611]. AAO is able to catalyze the oxidative dehydrogenation of a wide range of aromatic and aliphatic primary polyunsaturated

\footnotetext{
* Corresponding author. Fax: +351 253510271

E-mail address: artur@det.uminho.pt (A. Cavaco-Paulo).
}

alcohols. During catalysis the non-covalently bound FAD cofactor is reduced by the substrate and subsequently reoxidized by molecular oxygen to yield hydrogen peroxide (Fig. 1) [11,12]. This reaction can be detected amperometrically on the basis of the response achieved due to the generated hydrogen peroxide electrooxidation or due to the electrooxidation of the $\mathrm{FADH}_{2}$.

The successful heterologous expression of this oxidase in Emericella nidulans (conidial state: Aspergillus nidulans) and Escherichia coli has permitted to obtain high levels of recombinant AAO $(\mathrm{AAO} *)$ exhibiting similar catalytic properties to those observed for the wild enzyme produced by Pleurotus eryngii $[13,14]$, that can be used for a wide biochemical characterization. The molecular model of AAO from P. eryngii (PDB entry $1 \mathrm{QJN}$ ) showed that it is a globular protein with common features with the overall structure topology of the other members of Glucose-Methanol-Choline oxidoreductases (GMC) family, where this oxidase has been included recently $[15,16]$. AAO substrate-binding pocket is located on the si side of the flavin ring and connected to the exposed surface by a hydrophobic substrate access channel. The role of AAO active-site residues have been recently evaluated by site directed mutagenesis [17]. Two putative catalytic histidines (H502 and H546) are essential in AAO activity as a possible general bases in AAO catalysis. Moreover, an aromatic residue (F501), located near of cofactor and the putative catalytic histidines are also involved in substrate oxidation by AAO. 


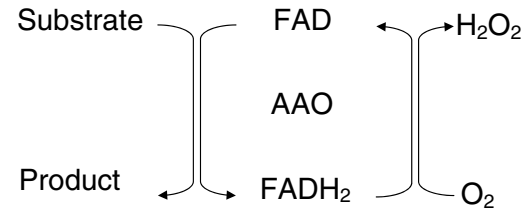

Fig. 1. Schematic representation of the oxidation reaction catalyzed by AAO.

In this study, we used a voltammetric technique to measure the redox potential of native $\mathrm{AAO} *$ and two F501 variants (F501A and F501Y). To better characterize these enzymes, electrochemical measurements were performed in order to determine the kinetic constants. The obtained results are compared with the ones previously obtained from spectrophotometric steady-state kinetics experiments $[12,13]$.

\section{Experimental}

\subsection{Chemicals}

Phosphate buffer salts were of analytical grade and obtained from Merck, Darmstadt, Germany. The enzyme substrates (Fig. 2) veratryl (3,4-dimethoxybenzyl) alcohol, anisyl (4-methoxybenzyl) alcohol, and benzyl alcohol were purchased from Sigma, St. Louis, MO, USA. All aqueous solutions were prepared using distilled water.

\subsection{AAO expression and site directed mutagenesis}

Native $\mathrm{AAO} *$ was produced in E. nidulans and E. coli according to the protocols described by Varela et al. [16] and Ruiz-Dueñas et al. [13]. AAO * variants, F501A and F501A, were obtained by PCR with the Quick-change site-directed mutagenesis kit from Stratagene (La Jolla, CA, USA) and used to transform E. nidulans [17].

\subsection{Electrode preparation}

The AAO modified electrodes were prepared using rods of solid spectroscopic graphite (SGL Carbon, Werke Ringsdorff, Bonn, Germany, type RW001, $3.05 \mathrm{~mm}$ diameter). The graphite rods were first polished on wet fine-structured emery paper (grit size: P1200) and then additionally polished on paper to obtain a mirror-like surface. The electrode rods were carefully rinsed with deionised water and allowed to dry at room temperature. A $10 \mu \mathrm{l}$ aliquot of the enzyme solution was added to each of the polished ends of the graphite rods and the adsorption was allowed to proceed for $1 \mathrm{~h}$ at $4{ }^{\circ} \mathrm{C}$. The enzyme electrodes were then thoroughly
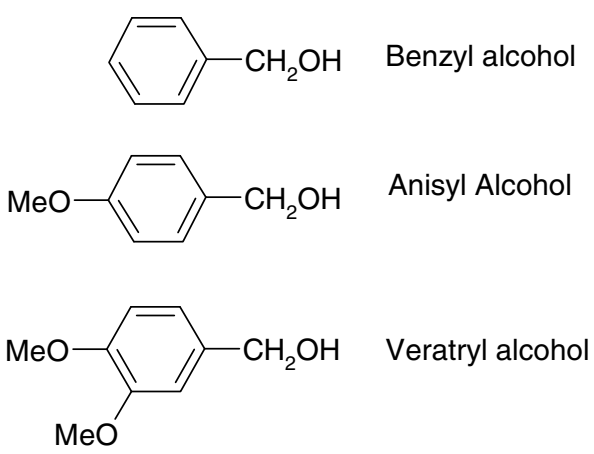

Fig. 2. Chemical structure of the three aromatic alcohols used as AAO substrates in this study. rinsed with $0.1 \mathrm{M}$ phosphate buffer, $\mathrm{pH} 5.5$, and if not immediately used, they were stored in the same buffer at $4{ }^{\circ} \mathrm{C}$. Weakly adsorbed enzymes were desorbed before measurements, by rotating the electrode in buffer for at least $30 \mathrm{~min}$.

\subsection{Electrochemical measurements}

The enzyme modified electrode was placed in a three-electrode cell with an $\mathrm{Ag} / \mathrm{AgCl}(3 \mathrm{M} \mathrm{NaCl})$ reference electrode (BAS, Bioanalytical Systems, West Lafayette, IN, USA) and a platinum wire auxiliary electrode. The electrodes were connected to a Voltalab 30 Potentiostat (Radiometer Analytical) controlled by the Voltamaster 4 (version 5.6) electrochemical software. All amperometric measurements were performed at an applied potential of $-50 \mathrm{mV}$ vs. $\mathrm{Ag} / \mathrm{AgCl}[18,19]$ with an electrolyte of $0.1 \mathrm{M}$ phosphate buffer, $\mathrm{pH}$ 5.5. The current was registered at a constant rotation speed of $500 \mathrm{rpm}$.

Cyclic voltammetry experiments were performed at a scan rate of $5 \mathrm{mV} / \mathrm{s}$. The redox potential of the enzymes was determined with the enzymes adsorbed onto graphite electrodes and with the enzymes in solution. In the latter case as working electrode was used a glassy carbon electrode. Prior to experiments, the solution was bubbled with nitrogen for $15 \mathrm{~min}$. Nitrogen was passed over the solution during the experiments. To evaluate the possible contribution of the enzyme physically adsorbed on glassy carbon electrode surface the blank test was made. The glassy carbon electrode was immersed in an enzyme solution for about $2 \mathrm{~h}$, then thoroughly rinsed and tested for the enzymatic activity using veratryl alcohol. No activity was observed. Therefore, it was considered that the adsorbed enzyme does not have any contribution.

\section{Results and discussion}

\subsection{Cyclic voltammetry studies}

Cyclic voltammograms of the studied AAOs were recorded in $0.1 \mathrm{M}$ phosphate buffer, $\mathrm{pH} 5.5$, at a scan rate of $5 \mathrm{mV} / \mathrm{s}$ between the extremes -400 and $700 \mathrm{mV}$ vs. $\mathrm{Ag} / \mathrm{AgCl}$. Fig. 3 presents a cyclic voltammogram of the native $\mathrm{AAO} *$ expressed in E. nidulans in solu-

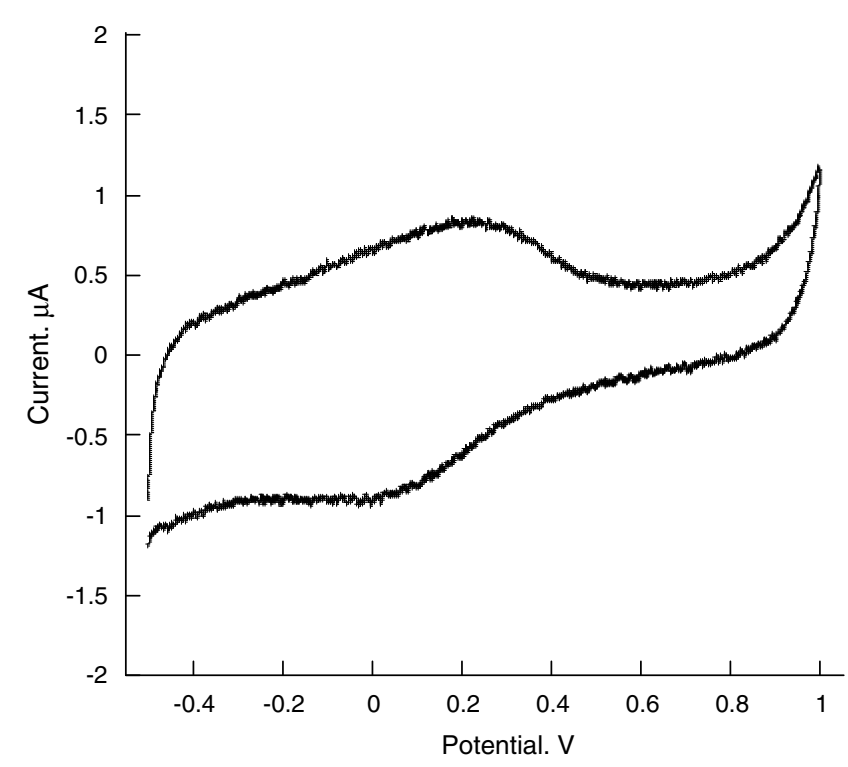

Fig. 3. Cyclic voltammogram of the native $A A O *$ from E. nidulans in solution, $0.1 \mathrm{M}$ phosphate buffer pH 5.5 at $5 \mathrm{mV} / \mathrm{s}$ (glassy carbon as working electrode). 
tion using glassy carbon as working electrode. From the cyclic voltammograms obtained, the AAO redox potential was calculated, and the results are presented in Table 1 . As it can be seen from this table, when the enzymes are adsorbed onto the graphite electrodes the redox potentials are higher than in the solution. In the case of the E. coli recombinant AAO the increase is much smaller than in the other cases. This can be justified by the lack of glycosylation of the enzyme expressed in a prokaryotic organism. It is also interesting to observe that the F501A variant showed lower redox potential than the native (non-mutated) enzyme, while the redox potential of the other variant (F501Y) was higher. This result confirms the role of Phe501 in AAO redox potential suggested in previous steady-state kinetic studies by Ferreira et al. (2006) [11]. This can be explained by considering the mutations that were done: a phenylalanine residue was changed to alanine in F501A and a phenylalanine residue changed to tyrosine in F501Y

Table 1

Redox potential of native $\mathrm{AAO} *$, expressed in E. nidulans and E. coli, and F501A and F501Y variants, expressed in E. nidulans, measured in solution (using a glassy carbon electrode) or adsorbed on a graphite electrode ( $\mathrm{mV} v \mathrm{vs} . \mathrm{Ag} / \mathrm{AgCl}$ )

\begin{tabular}{ccllc}
\hline & $\begin{array}{l}\mathrm{AAO} *(E . \\
\text { nidulans })\end{array}$ & $\begin{array}{l}\mathrm{AAO} * \\
(E . \text { coli })\end{array}$ & $\begin{array}{l}\mathrm{F501 \textrm {A } (}(E . \\
\text { nidulans })\end{array}$ & $\begin{array}{l}\mathrm{F501Y}(E . \\
\text { nidulans })\end{array}$ \\
\hline $\begin{array}{c}\text { Enzyme in } \\
\text { solution }\end{array}$ & $13.6 \pm 3.8$ & $28.8 \pm 4.7$ & $-40.8 \pm 5.9$ & $52.9 \pm 6.1$ \\
$\begin{array}{c}\text { Adsorbed } \\
\text { enzyme }\end{array}$ & $223.4 \pm 12.4$ & $64.4 \pm 5.3$ & $124.7 \pm 8.4$ & $145.9 \pm 9.8$ \\
\hline
\end{tabular}

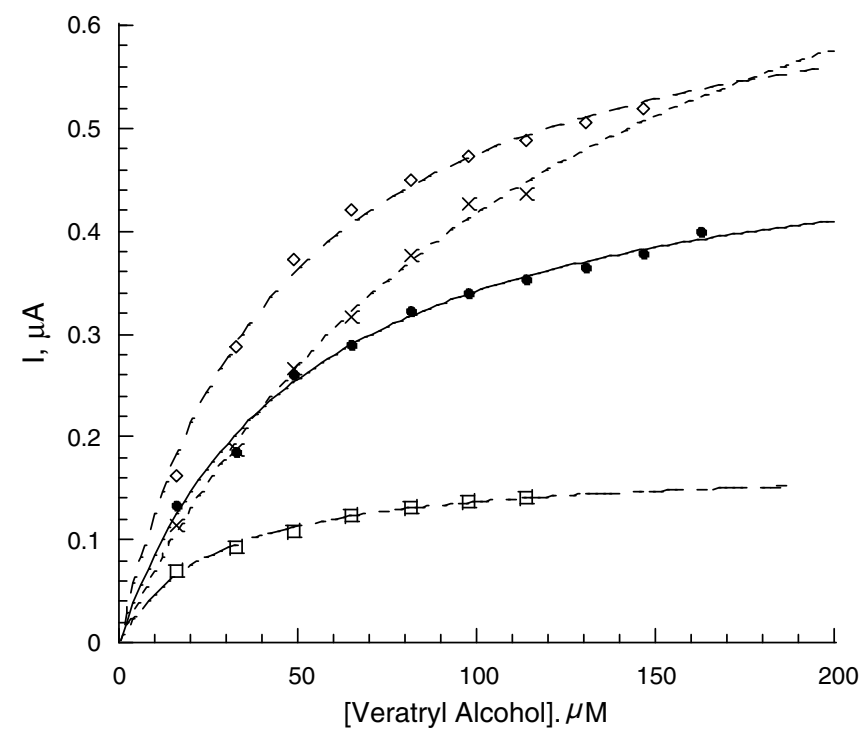

Fig. 4. Calibration graph obtained for the oxidation of veratryl alcohol using graphite electrodes modified with: - - AAO * from E. nidulans ; $\square-\mathrm{AAO} *$ from E. coli; $\diamond$ - F501A from E. nidulans; $\times$ - F501Y from E. nidulans. (the former change being more drastic than the second one, where one aromatic residue is substituted by other aromatic residue).

In the literature was found that for other oxidases the redox potential for the oxidazed-fully reduced free flavin is $-207 \mathrm{mV}$ in aqueous solution [20]. However, the redox potential of flavo-oxidases is strongly modulate by cofactor environment. In fact, protein-bound flavins exhibit wide range redox potentials from $-400 \mathrm{mV}$ to $+60 \mathrm{mV}$. Thus, vanillyl-alcohol oxidases from Penicillium simplicissimum has a high redox potential $(+55 \mathrm{mV})$ [21]. In the opposite way, we can find the reduction potential of nitroalkane oxidase from Fusarium oxysporium $(-365 \mathrm{mV})$ [22]. For both cases, and in general for other flavoenzymes, the determinations of their redox potentials were done spectrophotometrically with the enzyme in solution.

\subsection{Kinetic constants for AAOs oxidation of different substrates}

In this work the amperometric measurements were performed using the enzyme modified graphite electrode as working electrode, rotating at $500 \mathrm{rpm}$. The responses are dependent on the concentration of the substrate in the solution of interest. At higher substrate concentrations the current-concentration dependence gradually reached saturation (Fig. 4). The apparent Michaelis-Menten constants $\left(K_{\mathrm{m}}^{\mathrm{app}}\right)$ and maximal currents $\left(I_{\max }\right)$ have been calculated by fitting the variation of current-concentration dependencies of the analyzed compounds to the electrochemical Michaelis-Menten equation (Table 2) [23]. The kinetics of the reactions are firstly affected by the affinity between enzyme and the mediator. An estimation of this influence can be done by amperometric measurements in terms of $I_{\max } / K_{\mathrm{m}}^{\mathrm{app}}$ ratio. These parameters are often calculated in the design of enzymatic sensors to evaluate the sensitivity of the system proposed, which is related to the low or high affinity of the enzyme towards a specific substrate.

Comparing these results with the ones obtained from the spectrophotometric measurements by Ferreira et al. [17] it can be observed that $K_{\mathrm{m}}^{\mathrm{app}}$ values obtained from the amperometric measurements vary in the same way as the ones from spectrophotometric measurements when $p$-anisyl alcohol is used as a substrate. Regarding the affinity of the F501A and F501Y for veratryl alcohol or benzyl alcohol I used as substrate, the obtained results can be explained based on the different behavior of the immobilized mutants on the electrode surface than when in solution.

\section{Conclusion}

From the cyclic voltammetry experiments it was possible to calculate the redox potential of recombinant AAO produced in $E$. nidulans and E. coli, as well as the F501A and F501A enzyme variants expressed in the former system. The redox potentials of these enzymes were obtained for the enzymes adsorbed on graphite electrodes or with the enzymes in solution. Based on the kinetic values it can be concluded that these enzymes can be also used

Table 2

Michaelis-Menten constants obtained for the graphite modified electrodes

\begin{tabular}{|c|c|c|c|c|c|c|c|c|c|}
\hline & \multicolumn{3}{|c|}{ Anisyl alcohol } & \multicolumn{3}{|c|}{ Benzyl alcohol } & \multicolumn{3}{|c|}{ Veratryl alcohol } \\
\hline & $I_{\max }(\mu \mathrm{A})$ & $K_{\mathrm{m}}(\mu \mathrm{M})$ & Sensitivity $(\mathrm{nA} / \mu \mathrm{M})$ & $I_{\max }(\mu \mathrm{A})$ & $K_{\mathrm{m}}(\mu \mathrm{M})$ & Sensitivity $(\mathrm{n} A / \mu M)$ & $I_{\max }(\mu \mathrm{A})$ & $K_{\mathrm{m}}(\mu \mathrm{M})$ & Sensitivity $(\mathrm{nA} / \mu \mathrm{M})$ \\
\hline $\mathrm{AAO} *($ E. nidulans $)$ & $2.30 \pm 0.20$ & $794 \pm 24$ & $2.90 \pm 0.28$ & $0.70 \pm 0.26$ & $390 \pm 10$ & $1.70 \pm 0.13$ & $0.50 \pm 0.04$ & $50 \pm 4$ & $10.20 \pm 0.11$ \\
\hline $\mathrm{AAO} *($ E. coli $)$ & $1.20 \pm 0.10$ & $836 \pm 14$ & $1.40 \pm 0.12$ & $1.40 \pm 0.49$ & $947 \pm 16$ & $1.60 \pm 0.16$ & $0.20 \pm 0.03$ & $27 \pm 3$ & $6.40 \pm 0.08$ \\
\hline F501A (E. nidulans) & $0.20 \pm 0.01$ & $108 \pm 10$ & $2.00 \pm 0.18$ & $1.00 \pm 0.36$ & $51 \pm 4$ & $19.10 \pm 1.32$ & $0.70 \pm 0.05$ & $44 \pm 4$ & $15.50 \pm 0.27$ \\
\hline F501Y (E. nidulans) & $0.30 \pm 0.01$ & $120 \pm 13$ & $2.70 \pm 0.24$ & $0.70 \pm 0.31$ & $189 \pm 12$ & $3.50 \pm 0.47$ & $0.90 \pm 0.04$ & $123 \pm 16$ & $7.60 \pm 0.32$ \\
\hline
\end{tabular}


for construction of biosensors for detection of different substrates of interest.

\section{Acknowledgement}

Florentina-Daniela Munteanu is grateful to the Romanian National Authority for Scientific Research for the financial support in projects CEEX-3179/2005, CEEX 77/2006 and to Security Through Science Programme NATO EAP.RIG.982234.

\section{References}

[1] T. Higuchi, Biochemistry and Molecular Biology of Wood, Springer Verlag, London, 1997.

[2] D. Fengel, G. Wegener, Wood: Chemistry, Ultrastructure, Reactions, De Gruyter, Berlin, 1984.

[3] T.K. Kirk, D. Cullen, Environmentally Friendly Technologies for the Pulp and Paper Industry, TAPPI Press, Atlanta, 1998. p. 273.

[4] T.K. Kirk, R.L. Farrell, Annu. Rev. Microbiol. 41 (1987) 465

[5] A.T. Martínez, M. Speranza, F.J. Ruiz-Dueñas, P. Ferreira, S. Camarero, F. Guillén, M.J. Martínez, A. Gutiérrez, J.C. del Río, Int. Microbiol. 8 (2005) 195-204.

[6] Y. Asada, A. Watanabe, Y. Ohtsu, M. Kuwahara, Biosci. Biotechnol. Biochem. 59 (1995) 1339-1341.

[7] V.C. Farmer, M.E.K. Henderson, J.D. Russell, Biochem. J. 74 (1960) 257-262.
[8] R. Bourbonnais, M.G. Paice, Biochem. J. 255 (1988) 445-450.

[9] F. Guillén, A.T. Martínez, M.J. Martínez, Appl. Microbiol. Biotechnol. 32 (1990) $465-469$.

[10] A. Muheim, R. Waldner, M.S.A. Leisola, A. Fiechter, Enzyme Microb. Technol. 12 (1990) 204-209.

[11] P. Ferreira, F.J. Ruiz-Dueñas, M.J. Martínez, W.J.H. van Berkel, A.T. Martínez, FEBS J. 273 (2006) 4778

[12] P. Ferreira, M. Medina, F. Guillén, M.J. Martínez, W.J.H. Van Berkel, A.T. Martínez, Biochem. J. 389 (2005) 731-738.

[13] F.J. Ruiz-Duenas, P. Ferreira, M.J. Martinez, A.T. Martinez, Prot. Expr. Purif. 45 (2006) 191-199.

[14] E. Varela, F. Guillén, A.T. Martínez, M.J. Martínez, Biochim. Biophys. Acta (BBA) - Prot. Struct. Molec. Enzymol. 1546 (2001) 107-113.

[15] M. Zamocky, M. Hallberg, R. Ludwig, C. Divne, D. Haltrich, Gene 338 (2004) 1.

16] E. Varela, M. Jesus Martinez, A.T. Martinez, Biochim. Biophys. Acta (BBA) - Prot Struct. Molec. Enzymol. 1481 (2000) 202-208.

[17] P. Ferreira, F.J. Ruiz-Dueñas, M.J. Martínez, W.J.H. van Berkel, A.T. Martínez, FEBS J. 273 (2006) 4778.

[18] A. Lindgren, F.-D. Munteanu, I.G. Gazaryan, T. Ruzgas, L. Gorton, J. Electroanal. Chem. 458 (1998) 113.

[19] T. Ruzgas, L. Gorton, J. Emnéus, G. Marko-Varga, J. Electroanal. Chem. 391 (1995) 41

[20] V. Massey, FASEB J. 9 (1995) 473.

[21] M.W. Fraaije, R.H.H. van den Heuvel, A. Mattevi, W.J.H. van Berkel, J. Mol. Catal. B: Enzym. 21 (2003) 43.

[22] G. Gadda, P.F. Fitzpatrick, Biochemistry 37 (1998) 6154

[23] F.R. Shu, G.S. Wilson, Anal. Chem. 48 (1976) 1679-1686. 